УДК 351.74: 075

https://doi.org/10.52058/2708-7530-2021-9(15)-99-110

Канарський Володимир Сергійович аспірант кафедр глобальної та національно безпеки, ННІ Публічного управління та державної служби КНУ імені Тараса Шевченка, вул. Антона Цедіка, 20, м. Київ, 03057, тел.: (093) 61991-17, e-mail: kanarsky.v@gmail.com, https://orcid.org/0000-0003-2112-3344

\title{
ПОЛІТИКО-ПРАВОВИЙ МЕХАНІЗМ ДЕРЖАВНОГО УПРАВЛІННЯ ІНФОРМАЦІЙНО-ПСИХОЛОГІЧНОЮ БЕЗПЕКОЮ УКРАЇНИ: СУТНІСТЬ, ФУНКЦІї ТА ПОВНОВАЖЕННЯ
}

Анотація. У статті досліджено сутність, функції та повноваження політикоправового механізму державного управління інформаційно-психологічною безпекою України. Зроблено аналіз наукових досліджень останніх років за обраною темою статті.

Запропоновано пропозиції щодо оптимізації політико-правових механізмів забезпечення інформаційно-психологічної безпеки країни.

Дається авторська трактовка концепту «інформаційно-психологічна безпека» та аналізується нормативно-правова основа забезпечення інформаційнопсихологічної безпеки в Україні. Окреслено першочергові управлінські завдання у сфері забезпечення інформаційно-психологічної безпеки особи, суспільства та держави.

За результатами проведеного аналізу історіографії проблеми доведено, що більшість досліджень механізму державного управління інформаційнопсихологічною безпекою присвячені саме інформаційній складовою національної безпеки. Проблеми формування та реалізації механізму інформаційнопсихологічної безпеки не є достатньо дослідженими.

Зазначається, що для створення в Україні розвиненого національного інформаційного простору і захисту іiі інформаційно-психологічного простору необхідна державна підтримка вітчизняного виробника інформаційної продукції та телекомунікаційного обладнання, національних операторів телекомунікацій, зокрема, шляхом створення нормативно-правових, фінансових, фіскальних та інших передумов.

У висновках наголошується, що інформаційно-психологічна безпека України не виділена як одна з визначальних у спектрі безпекових складових. Політикоправові механізми державного управління нею чітко не визначені, фрагментовані та неузгоджені, а передовий іноземний досвід не запроваджується. За роки незалежності України так і не було прийнято Закон України «Про інформаційнопсихологічну безпеку», де було б чітко визначено суб'єктів та політико-правові механізми іiі реалізації. 
Ключові слова: політико-правовий механізм, інформаційно-психологічна безпека, масова комунікація, інформаційно-психологічний простір.

Kanarsky Vladimir Sergeevich Graduate student of the Departments of Global and National Security, Institute of Public Administration and Civil Service of Taras Shevchenko National University, Anton Tsedik St., 20, Kyiv, 03057, tel.: (093) 61991-17, e-mail: kanarsky.v@gmail.com, https://orcid.org/0000-0003-2112-3344

\section{POLITICAL AND LEGAL MECHANISM OF THE STATE MANAGEMENT OF INFORMATION AND PSYCHOLOGICAL SECURITY OF UKRAINE: ESSENCE, FUNCTIONS AND POWERS}

Abstract. The article examines the essence, functions and powers of the political and legal mechanism of state management of information and psychological security of Ukraine. An analysis of scientific research in recent years on the selected topic of the article.

Proposals for optimizing political and legal mechanisms to ensure information and psychological security of the country are proposed.

The author's interpretation of the concept of "information and psychological security" is given and the normative and legal basis for ensuring information and psychological security in Ukraine is analyzed. The priority management tasks in the field of information and psychological security of the person, society and the state are outlined.

According to the results of the analysis of the historiography of the problem, it is proved that most studies of the mechanism of state management of information and psychological security are devoted to the information component of national security. Problems of formation and implementation of the mechanism of information and psychological security are not sufficiently studied.

It is noted that to create a developed national information space in Ukraine and protect its information and psychological space requires state support of domestic manufacturers of information products and telecommunications equipment, national telecommunications operators, in particular, by creating regulatory, financial, fiscal and other prerequisites.

The conclusions emphasize that the information and psychological security of Ukraine is not identified as one of the defining in the range of security components. The political and legal mechanisms of public administration are not clearly defined, fragmented and inconsistent, and best foreign practices are not implemented. During the years of Ukraine's independence, the Law of Ukraine "On Information and Psychological Security" was never adopted, which would clearly define the subjects and political and legal mechanisms of its implementation.

Keywords: political and legal mechanism, information and psychological security, mass communication, information and psychological space. 
Постановка проблеми. Напрацювання ряду напрямів дослідження механізмів забезпечення державного управління інформаційно-психологічною складовою національної безпеки є нагальною потребою сьогодення для України, особливо в умовах протидії агресору - Російській Федерації, що визначено рядом нормативно-правових актів України.

Потрібно зазначити, в державному управлінні на перше місце сьогодні висувається проблема ефективного управління інформаційно-психологічною безпекою держави. У свою чергу вчені стверджують, що передбачити всі можливі загрози в галузі інформаційної безпеки неможливо, оскільки вони здатні міняти свої зміст та динаміку, а правове регулювання вимагає стабільності. Саме тому наголошуємо на необхідності спрямовувати політику інформаційної безпеки не на пошук відповіді на певну загрозу, а на створення безпечних умов функціонування інформаційно-психологічної сфери, за яких ця сфера буде несприйнятливою до можливих негативних впливів, як всередині держави, так i ззовні.

У рамках аналізу інформаційної безпеки дослідники й практики звертають усе більшу увагу й на необхідність активної розробки проблематики інформаційно-психологічної безпеки особистості, суспільства та держави, адже без докладного аналізу цих проблем неможливий подальший стійкий розвиток суспільства.

Політико-правовий механізм державного управління інформаційнопсихологічною безпекою - це ефективно функціонуюча система засобів, заходів та важелів органів державної влади, яка виступає одночасно і суб'єктом i об'єктом забезпечення інформаційно-психологічної безпеки.

Від рівня розвитку інформаційно-психологічного простору вирішальним чином залежать поведінка людей, формування суспільно-політичних рухів, соціальна безпека.

Аналіз останніх досліджень і публікацій. Серед широкого спектру наукових досліджень останніх років можна згадати роботи, що розглядають питання державного управління національною та інформаційною безпекою. Це роботи таких авторів, як Ситник Г.П., Богданович В.Ю[1-2]; присвячені проблемам та технологіям забезпечення інформаційної безпеки в процесі політичних та соціальних комунікацій - Кормич Б.А., Манойло[3-4]; аналізу базових аспектів інформаційної безпеки під час процесу політичної комунікації Дубов Д.[5]; вивченню методів та засобів формування друкованими ЗМІ громадської думки в Україні відносно політичних сил держави - Ожеван М. Почепцов Г.Г.[6-7] та ін.

3 огляду на історичний досвід людства зазначимо, що нації, які не створили надійної та ефективно керованої системи безпеки, ризикують втратити свою самоідентичність, розчинитись в потоці історії. У результаті гіпертрофованого прагнення стати відкритим суспільством, Україна стала більш вразлива через неможливість запроваджувати дієві заходи контролю над інформаційними 
потоками. Сприяє такому стану речей і відсутність раціональної управлінської стратегії інформаційної безпеки і методів іiі реалізації. До однієї з головних причин цього слід віднести низький рівень знань керівників виконавчих органів влади всіх рівнів в питаннях інформаційних війн і інформаційних технологій i, вже як наслідок, - низьку обізнаність населення в питаннях забезпечення інформаційної безпеки.

Розв'язання проблеми забезпечення національної безпеки є невід'ємною і дуже складною функцією кожної незалежної держави i основною сферою діяльності іï політичних і державних інститутів [8, с. 65]. Найбільш фаховою, на нашу думку, є визначення поняття «безпека» як стан захищеності від можливого нанесення шкоди, здатність до стримування або протидія небезпечним впливам, а також до швидкої компенсації завданих збитків. Безпека означає збереження системою стабільності, стійкості та можливості саморозвитку.

Проблема безпеки розглядається в різних галузях наукового знання, та набуває ознак в залежності від профілю фахівців. Наприклад, в юридичній науці безпека розглядається як система встановлених законами правових гарантій захищеності особи і суспільства. 3 психологічної точки зору поняття «безпека» розкривається як відчуття, сприйняття і переживання потреби в захисті життєво важливих потреб і інтересів людей. У філософії безпека характеризується як стан, тенденції розвитку і умови життєдіяльності соціуму, його структур, інститутів $\mathrm{i}$ установ, при яких забезпечується збереження їх якісної визначеності, оптимальне співвідношення свободи і необхідності. У політологічному трактуванні безпека це властивість певної системи і результат діяльності ряду систем і органів держави, а також сам процес діяльності, направлений на досягнення поставлених завдань по забезпеченню захищеності особи, суспільства і держави.

А.Бурьяк досліджуючи національну безпеку трактує іï як «показник стану нації, що означає, що сукупний вплив внутрішніх і зовнішніх шкідливих чинників не може значно понизити якість іiі життя i створити загрозу іiі існуванню» [9].

І.Л.Прохоренко визначає національну безпеку як поєднання внутрішніх i зовнішніх обставин, які впливають на життя держави, при якому відсутні загрози критичного характеру і в той же час зберігається повноцінна здатність держави адекватно реагувати на ці загрози, якщо вони виникнуть» [10, с.99-100].

Ряд дослідників під безпекою розуміють систему гарантій, що забезпечує явищу його нормальний розвиток. Практично всі приведені вище результати досліджень визначення безпеки піддавалися і продовжують піддаватися критиці і з боку фахівців-практиків і з боку учених. Неспроможність багатьох визначень очевидна.

Проведений аналіз історіографії проблеми свідчить, що більшість досліджень механізму державного управління інформаційно-психологічною безпекою присвячені саме інформаційній складовою національної безпеки. Проблеми формування та реалізації механізму інформаційно-психологічної 
безпеки не є достатньо дослідженими.

Мета статті. Автор статті ставить за мету дослідити сутність, функції та повноваження політико-правового механізму державного управління інформаційно-психологічною безпекою України.

Виклад основного матеріалу. Можемо констатувати - безпека не може існувати без своєї діалектичної протилежності - небезпеки. Більш того, певний комплекс небезпек присутній завжди. Поняття ж «небезпека» в найзагальнішому плані необхідно досліджувати через характеристику стану об'єкту, при якому загроза його буттю за рахунок розриву або спотворення найбільш істотних зв'язків і стосунків в системі перевищує якусь гранично допустиму суб'єктивно встановлену величину.

Основним змістом діяльності інформаційної безпеки більшість спеціалістів бачить у неможливості заподіяння шкоди об’єкту захисту, його властивостям або діяльності з виконання своїх функцій.

Отже, під загальним поняттям «інформаційна безпека» в нормативноправових актах доцільно розмежувати це поняття на «інформаційно-технічну безпеку» та «інформаційно-психологічну безпеку».

Згідно Закону України «Про національну безпеку України», національна безпека - захищеність державного суверенітету, територіальної цілісності, демократичного конституційного ладу та інших національних інтересів України від реальних та потенційних загроз; [11].

Українські науковці В.Б.Толубко, С.Я.Жук, В.О.Косевцов [12, с.18-22] відмічають, що відповідно до загальної методології національної безпеки, інформаційна безпека повинна використовувати такі категорії, як «інформаційна сфера», «національні інтереси в інформаційній сфері», «об'єкт і суб'єкт інформаційної безпеки», «загрози інформаційній безпеці», «система забезпечення інформаційної безпеки», «політика забезпечення інформаційної безпеки» та ін. На даний час ця термінологія ще находиться у стані розвитку.

Під інформаційно-психологічною безпекою розуміють стан захищеності громадян, окремих груп та соціальних верств, масових об'єднань людей i населення в цілому від негативних інформаційно-психологічних об'єктів впливів. Це також і стан захищеності індивідуальної, групової й суспільної свідомості та соціальних суб'єктів різних рівнів від впливу інформаційних факторів, які викликають дисфункціональні соціальні процеси.

Даний стан дає змогу людині сформувати і відповідно належно використовувати систему адекватного сприйняття реальності й відношення до оточуючого світу і самої себе, що стає основою для подальшої соціальної поведінки людини; цей стан забезпечує цілісність людини як активного соціального суб'єкта й надає можливості для розвитку в умовах інформаційної взаємодії з оточуючим світом.

Інформаційно-психологічну безпеку особи та суспільства вважають окремою складовою національної безпеки держави та трактують як стан захищеності 
гарантованих законодавством умов життєдіяльності держави, суспільства та окремої особи від зовнішніх та внутрішніх загроз. Підтримання національної безпеки є важливим напрямом державної діяльності, що актуалізується залежно від наявності та ступеня відповідних загроз [13, с. 13].

На даний момент в Україні відсутня чітко виписане у чинному законодавстві функції та повноваження суб’єктів забезпечення інформаційно-психологічної безпеки. Вважаємо за доцільне вдосконалити організаційну складову даної сфери шляхом створення окремого органу при РНБО України, який би напрацював певну стратегію інформаційної політики у сферах інформаційно-технічної та інформаційно-психологічної безпеки. Відповідно виникає необхідність глибокого наукового дослідження 3 метою прогнозування особливостей функціонування цих політико-правових механізмів.

Інформаційне суспільство породило таку категорію як «інформаційне управління». Треба зазначити, що в теорії державного управління цей аспект проблеми ще тільки осмислюється [14, с.321]. Даний перспективний напрямок теоретичного дослідження теж ще чекає свого часу на реалізацію.

Саме зміни в характеристиках управління, пов'язані 3 трансформацією управління в маніпуляцію або іншими словами - злиттям понять «управління» та «інформація» в системі масових комунікацій. Найбільш повно маніпулятивні технології управління масовою комунікацією находять свою реалізацію в т.з. технологіях зв’язків з громадськістю (Public Relations). 3 більш ніж 500 визначень PR, прийнятих у всьому світі найбільш узагальненим та універсальним представляється наступне: PR - це управлінська діяльність, направлена на встановлення взаємовигідних комунікативних відносик між організацією та громадськістю, від якої залежить успіх функціонування даної організації. PR представляє собою самостійний вид діяльності організації.

Для узгодження з інформаційними процесами в системі масових комунікацій застосовується також мотиваційне управління як частина загального процесу управління, що забезпечує усвідомлення і вибір способів перетворення впливів зовнішнього i внутрішнього середовищ на основі оцінювання ситуації, ціліполагання, прийняття рішень, очікування i коректування відповідних результатів діяльності.

Дослідження мотиваційного управління, яке по суті $\epsilon$ різновидом інформаційного управління, що застосовується для управління соціальними комунікативними системами свідчить, що процеси управління завжди мають місце там, де здійснюється загальна діяльність людей для досягнення певних результатів. Управління здійснюється за загальними законами у всіх складних динамічних системах - соціальних, біологічних, технічних, економічних і ін. - i основане на отриманні, обробці і передачі інформації.

Основним нормативними докумепнтами, що регламентують управлінську діяльність в сфері інформаційної політики є ряд Законів України «Про інформацію», «Про друковані засоби масової інформації (пресу) в Україні», «Про 
телебачення i радіомовлення», «Про інформаційні агентства», «Про порядок висвітлення діяльності органів державної влади та органів місцевого самоврядування в Україні засобами масової інформації», «Про Національну раду України 3 питань телебачення і радіомовлення», «Про систему Суспільного телебачення i радіомовлення України», «Про рекламу», «Про державну підтримку засобів масової інформації», «Про соціальний захист журналістів».

3 метою покращення державного управління інформаційно-психологічною безпекою необхідно дослідити результати можливих змін до чинного законодавства щодо: запобігання процесам концентрації власності та монополізації вітчизняного інформаційного ринку (субринків), зокрема телебачення i радіомовлення; забезпечення прозорості відносин власності стосовно засобів масової інформації з метою унеможливлення маніпулювання громадською свідомістю; удосконалення процедури реєстрації та перереєстрації друкованих засобів масової інформації; встановлення відповідальності за порушення законодавства у сфері захисту суспільної моралі.

Для успішної реалізації державницької політики в сфері масових комунікацій необхідно внести ряд змін до Закону України «Про телебачення $\mathrm{i}$ радіомовлення» 3 метою: заборонити створення і діяльність телерадіоорганізацій, засновником (співзасновниками) яких $\epsilon$ нерезидент (нерезиденти), зареєстрований (зареєстровані) в офшорних зонах або в країнах, законодавство яких не передбачає надання інформації про засновників або власників за запитом української сторони; поетапного встановлення квот щодо присутності в ефірі телерадіоорганізації аудіовізуального продукту, виробленого в одній країні.

Також необхідно здійснити впровадження широкодоступного цифрового мовлення у прийнятні строки; реалізувати заходи щодо створення та належного функціонування системи суспільного телебачення і радіомовлення з урахуванням необхідності захисту суспільної моралі, інтересів, культурних цінностей та плюралізму засобів масової інформації під час впровадження цифрового мовлення.

Забезпечення розвитку сфери телебачення i радіомовлення вимагає: збільшення покриття території України телерадіомовленням вітчизняних аудіовізуальних засобів масової інформації, зокрема в районах ОРДЛО та на тимчасово окупований Крим. Система масових комунікацій в Україні буде неповною та відсталою без розвитку власного супутникового мовлення.

Необхідно вдосконалювати кабельне телерадіомовлення, модернізувати мережі поширення програм національного радіомовлення, оптимізувати та поновити роботу мереж середньохвильового та короткохвильового радіомовлення із збільшенням загального охоплення програмами населення в сільській місцевості, гірських районах та населених пунктах, де відбулася найбільша руйнація системи дротового мовлення.

Першочерговим управлінським завданням виступає розробка комплексної програми розвитку державної телерадіокомпанії «Культура» 3 урахуванням 
необхідності створення системи суспільного мовлення; використання широкосмугових телекомунікаційних мереж 3 високою пропускною здатністю для забезпечення Інтернет-мовлення.

Потребує вдосконалення державне управління Українським національним інформаційним агентством «Укрінформ» 3 метою підвищення ефективності його діяльності до рівня провідних європейських інформаційних агентств.

Не в останню чергу стоїть завдання дослідження розширення міжнародного співробітництва в інформаційній сфері, зокрема сприяння обміну інформаційними продуктами між вітчизняними та зарубіжними засобами масової інформації.

Для організації ефективної взаємодії з українською діаспорою необхідно налагодити співробітництво між вітчизняними засобами масової інформації та засобами масової інформації українських громад за кордоном.

Не обійдеться Україна і без розширення мережі кореспондентських пунктів вітчизняних ЗМІ за кордоном, створення належних умов для їх діяльності.

Надійним способом формування позитивного іміджу України на міжнародній арені є збільшення обсягів розповсюдження за кордоном вітчизняної друкованої продукції, зокрема іноземними мовами; забезпечення трансляції програм вітчизняного телерадіомовлення на територію інших країн, зокрема шляхом розроблення та виконання комплексної програми розвитку державної телерадіокомпанії «Всесвітня служба «Українське телебачення і радіомовлення» та «Всесвітньої служби «Радіо Україна» Національної радіокомпанії України; [15].

Уряд України уповноважить главу міністерства культури і інформаційної політики (МКІП) Олександра Ткаченко на підписання угоди 3 Euronews про запуск медіапроекту Euronews Ukraine у 2021 році. Функціонування української редакції міжнародного телевізійного каналу «Свроньюс» було припинено у 2017 році. Договір про створення української служби Euronews був укладений в жовтні 2010 року між національною телекомпанією України (НТКУ) і європейським інформаційним телеканалом. У 2014 році нове керівництво НТКУ заявило про припинення відносин як невигідних 3 фінансової точки зору для української сторони, а також через неможливість впливати на контент української версії Euronews. Глава НТКУ Зураб Аласанія в січні 2015 року говорив, що заборгованість НТКУ перед Euronews становила на той момент 11 млн євро.

Завдання держави постійно вживати заходи, спрямовані на розширення сфери використання української мови як комунікативного засобу в національному інформаційному просторі України, політико-правовими механізмами державного управління не дати зруйнувати мовно-інформаційний український простір, демонтувати колективну національну пам'ять.

Світовий досвід показує, що держава повинна встановлювати заохочувальні тарифи, ставки, пільги, а також обов'язкові норми на поширення інформаційної продукції, виконання художніх творів українською мовою вітчизняними i зарубіжними виробниками, авторами тощо. Держава в свою чергу, відповідно до 
законів України, гарантує вільне використання в інформаційній діяльності мов народів і національних меншин України.

Держава повинна контролювати збереження, реконструкцію та реорганізацію елементів і об'єктів інформаційної інфраструктури провідного значення незалежно від форм власності на них шляхом управління ними ліцензуванням та реєстраційними процедурами, сприяти дослідженню та впровадженню новітніх комунікативних технологій в інформаційній інфраструктурі України, створювати сприятливі умови для проведення науководослідних та конструкторських робіт у цій галузі.

Збір зарубіжними представниками на території України відкритої інформації та переміщення інформації через кордон необхідно обмежувати законодавчо на підставі інтересів національної безпеки, контролювати митними органами та органами охорони державної таємниці відповідно до законів України.

Процес реформування Збройних сил України також супроводжується радикальними змінами в інформаційній сфері, а отже, особливої актуальності набуває потреба дослідження удосконалення наявних комунікативних систем зв'язку і автоматизації.

3 досвіду інших країн наведемо приклад, для покращення державного управління масовими комунікаціями у воєнній сфері в США розробив версію Інтернету для військових цілей, оскільки нові мережеві загрози і атаки вимагають революційних підходів до забезпечення інформаційної безпеки. Компанія «Локхід Мартін» отримала контракт на суму 31 млн. доларів від Агентства перспективних оборонних розробок DARPA США. Інструменти, які розроблені в рамках нового проекту, забезпечують боєздатність армії США навіть в умовах масованих кібератаки [16.].

Отже, для створення в Україні розвиненого національного інформаційного простору і захисту ії інформаційно-психологічного простору необхідна державна підтримка вітчизняного виробника інформаційної продукції та телекомунікаційного обладнання, національних операторів телекомунікацій, зокрема, шляхом створення нормативно-правових, фінансових, фіскальних та інших передумов.

Зауважимо, що сьогоднішня ситуація 3 управлінням інформаційнопсихологічною безпекою України призвела до того, що держава знаходиться в стані системної дезорганізації, яка проявляється в тому, що держава не являється чітко вираженим суб'єктом управління і розвитку, вона не сформувала прозору стратегію розвитку (яку розуміє і сприймає домінуюча частина населення), не забезпечила нормальні умови життя своїм громадянам, не гарантує дотримання основних конституційних прав. Це відбувається в наслідок нездатності України адекватно реагувати на професійно організовані рядом країн інформаційнопсихологічні операції, спрямовані на перехоплення державного управління.

Пропозиції щодо оптимізації політико-правових механізмів забезпечення інформаційно-психологічної безпеки: Генеральній прокуратурі посилити нагляд 
за додержанням і застосуванням законодавства про свободу слова та права на інформацію, перевірити факти неправомірних дій окремих установ і посадових осіб органів державної влади тощо; Національній раді 3 питань телебачення i радіомовлення забезпечити вимоги законодавства щодо контролю за реалізацією інформаційної політики держави в сфері телебачення і радіомовлення, а також посилити власну роль і відповідальність за розвиток та якісний стан телебачення й радіомовлення України, за зростання професійного, художнього рівня програм та передач телерадіоорганізацій тощо; органам місцевого самоврядування та державної виконавчої влади на місцях спільно з Фондом державного майна забезпечити ефективний захист майнових прав суб'єктів інформаційновидавничої сфери комунальної та інших форм власності. Не допускати вилучення 3 цієї сфери та передачі для використання не за призначенням приміщень, устаткування та обладнання, іншого майна друкарень, редакцій, періодичних видань, телерадіоорганізацій і земельних ділянок, на яких ці об'єкти розташовані.

Висновки. Аналіз наукової літературі з дослідження державного управління інформаційно-психологічною безпекою України показав, що цей напрям управлінської діяльності тільки викристалізовуються та здійснюється пошук їх оптимальних варіантів.

Сьогодні людство стоїть перед викликом гібридних війні. Саме такі війни породжують формування нового гібридного світу, точніше, - гібридного світоустрою. Точкою відліку для формування гібридного світоустрою стала агресія Росії проти України. Пряма анексія Криму Росією та іiі дії на Донбасі основою початку нової світової гібридної війни. Саме за таких умов стає очевидним зростання впливу засобів масової комунікації та масової культури в цілому на динаміку соціальних і комунікаційних процесів. Сучасні виклики часу вимагають створення ефективної комплексної системи державного управління інформаційно-психологічним простором.

Ключова проблема інформаційної (інформаційно-технічної та інформаційнопсихологічної) безпеки України - це проблема концептуального, доктринального i законодавчого ii забезпечення, формування комплексу нормативно-правових регуляторів даної сфери. На даний момент, нажаль, таке забезпечення або відсутнє, або є неадекватним дійсності, штучно підігнаним під кон'юнктурні вимоги. Концептуально національну інформаційно-психологічну безпеку автор пропонує розглядати як провідний вид суспільних інформаційно-психологічних відносин щодо недопущення або зведення до мінімуму шкоди, що завдається життєво важливим інтересам особи, суспільства, держави.

Сьогоднішня ситуація 3 недосконалістю державного управління інформаційно-психологічною безпекою України призвела до того, що держава знаходиться в стані системної дезорганізації, посиленою негативними наслідками агресії з боку Росії, в якому вона не стала чітко вираженим суб’єктом управління та розвитку.

Аналіз стану захищеності інформаційно-психологічного простору України 
свідчить, що вивченню всього комплексу проблем. повязаних В результаті прагнення стати відкритим суспільством, Україна стала більш вразлива через неможливість запроваджувати дієві заходи контролю над інформаційними потоками. Сприяє такому стану речей і відсутність раціональної управлінської стратегії інформаційної безпеки і методів їі реалізації.

Інформаційно-психологічна безпека України не виділена як одна 3 визначальних у спектрі безпекових складових. Політико-правові механізми державного управління нею чітко не визначені, фрагментовані та неузгоджені, а передовий іноземний досвід не запроваджується. За роки незалежності України так і не було прийнято Закон України «Про інформаційно-психологічну безпеку», де було б чітко визначено суб'єктів державної політики національної безпеки у даній сфері діяльності та політико-правові механізми її реалізації.

Перспективи подальших розвідок у даному напрямі автор бачить у розробки змісту та концептуальних основ інших механізмів державного управління інформаційно-психологічною безпекою України.

\section{Jimepamypa:}

1. Богданович В.Ю. Інформаційна безпека та шляхи іï забезпечення : навч. посіб. / В.Ю. Богданович ; [у 2 ч. : Основні засади забезпечення інформаційної безпеки]. К. : Вид-во НАУ, 2005. Ч. II. 342 c.

2. Бурьяк А. Национальная безопасность. Отрывки. URL: http://bouriac.narod.ru

3. Військовий Інтернет. Ньюсленд. 08.11.2009. URL: http://newsland.ru/news/article.htm.

4. Дубов Д. Інформаційна безпека в умовах впровадження електронного урядування. Вісник книжкової палати. 2006. № 7. С. 34-38.

5. Концепція державної інформаційної політики. Сучасний стан інформаційної сфери, визначення проблем на розв'язання яких спрямована концепція . URL: http://w1.c1.rada.gov.ua/pls/zweb2/webproc34?id=\&pf3511=38772\&pf35401=174806

6. Кормич Б.А. Організаційно-правові основи політики інформаційної безпеки України: автореф. дис. на здобуття наук. ступеня д-ра юрид. наук / Б.А. Кормич. Харків, 2004. 44 с, с. 16.

7. Кормич Б.А. Суб'єктно-об'єктний склад інформаційної безпеки. Актуальні проблеми політики. 2003. Вип. 8. С. 130-137.

8. Манойло А.В. Государственная информационная политика в условиях информационно -психологической войны : монография / Манойло А.В., Петренко А.И. ; под заг. ред. А.В.Манойло. М. : Горячая линия - Телеком, 2003. 317 с., с. 111;

9. Ожеван М. Фронти й тили великих інформаційних війн. Підприємництво в Україні. 2001. № 4-5.

10. Основи національної безпеки України. Навчальний посібник. / Смолянюк В .Ф., Деменко О. Ф., Прибутько П. С. К.: Паливода А. В., 2017. 140 с.

11. Почепцов Г.Г. Інформаційні війни. Військо України. 2001. № 3-4. С. 20.

12. Про національну безпеку України: Закон України № 2469-VIII від 21 червня 2018 року. URL:: https://zakon.rada.gov.ua/laws/show/2469-19\#Text.

13. Прохоренко И.Л. Национальная безопасность и баланс сил. Баланс сил в мировой экономике: теория и практика. М. : Знание, 1993. 185 с.

14. Ситник Г.П. Державне управління національною безпекою теорія i практика : [монографія]. К. : Вид-во НАДУ, 2004. 408 с. 
15.Соціально-правові основи інформаційної безпеки : [навч. посібник / за ред. В.В. Остроухова. К. : Росава, 2007. 496 с.

16. Толубко В.Б. Концептуальні основи інформаційної безпеки України / Толубко В.Б., Жук С.Я., Косевцов В.О. Наука і оборона. № 2. 2004. С.18-22.

\section{References:}

1. Bogdanovich, V.Ju. (2005). Informacijna bezpeka ta shljahi ï zabezpechennja [Information security and ways to ensure it]. Riev: Vid-vo NAU [in Ukrainian].

2. Bur'jak A. Nacional'naja bezopasnost'. Otryvki. URL: http://bouriac.narod.ru

3. Vijs'kovij Internet. N'juslend. 08.11.2009. URL: http://newsland.ru/news/article.htm.

4. Dubov, D. (2006). Informacijna bezpeka $v$ umovah vprovadzhennja elektronnogo urjaduvannja [Information security in the implementation of e-government]. Visnik knizhkovoï palati Bulletin of the Book Chamber, 7, 34-38 [in Ukrainian].

5. Koncepcija derzhavnoï informacijnoï politiki. Suchasnij stan informacijnoï sferi, viznachennja problem na rozv'jazannja jakih sprjamovana koncepcija . URL: http://w1.c1.rada.gov.ua/pls/zweb2/webproc34?id=\&pf3511=38772\&pf35401=174806

6. Kormich, B.A. (2004) Organizacijno-pravovi osnovi politiki informacijnoï bezpeki Ukraïni [Organizational and legal bases of information security policy of Ukraine]. Extended abstract of Doctor's thesis. Kharkiv [in Ukrainian].

7. Kormich, B.A. (2003). Sub'єktno-ob'єktnij sklad informacijnoï bezpeki [Subject-object composition of information security]. Aktual'ni problemi politiki - Current policy issues, 8, 130-137 [in Ukrainian].

8. Manojlo, A.V. (2003). Gosudarstvennaja informacionnaja politika v uslovijah informacionno -psihologicheskoj vojny [State information policy in the conditions of information-psychological war]. Moscow: Gorjachaja linija - Telekom [in Russian].

9. Ozhevan, M. (2001). Fronti j tili velikih informacijnih vijn [Fronts and rear of the great information wars]. Pidpriemnictvo v Ukraïni - Entrepreneurship in Ukraine, 4-5 [in Ukrainian].

10. Smoljanjuk, V .F., Demenko, O. F., Pribut'ko, P. S. (207) Osnovi nacional'noï bezpeki Ukraïni [Fundamentals of national security of Ukraine]. Kiev: Palivoda A. V. [in Ukrainian].

11. Pochepcov, G.G. (2001). Informacijni vijni [Information wars]. Vijs'ko Ukraïni - The Army of Ukraine, 3-4, 20 [in Ukrainian].

12. Zakon Ukrainy «Pro nacional'nu bezpeku Ukraïni» [The Law of Ukraine «On the national security of Ukraine»]. (n.d.). zakon.rada.gov.ua. Retrieved from https://zakon.rada.gov.ua/laws/ show/2469-19\#Text [in Ukrainian].

13. Prohorenko, I.L. (1993). Nacional'naja bezopasnost' $i$ balans sil. Balans sil v mirovoj jekonomike: teorija i praktika [National security and balance of power. Balance of power in the world economy: theory and practice]. Moscow: Znanie [in Russian].

14. Sitnik, G.P. (2004) Derzhavne upravlinnja nacional'noju bezpekoju teorija i praktika [State management of national security theory and practice]. Kiev: Vid-vo NADU [in Ukrainian].

15. Ostrouhova ,V.V. (2007). Social'no-pravovi osnovi informacijnoï bezpeki [Socio-legal foundations of information security]. Kiev: Rosava [in Ukrainian].

16. Tolubko, V.B., Zhuk, S.Ja., Kosevcov, V.O. (2004). Konceptual'ni osnovi informacijnoï bezpeki Ukraïni [Conceptual bases of information security of Ukraine]. Nauka i oborona- Science and defense, 2, 18-22 [in Ukrainian]. 